\title{
Analysis of the Performance of Municipalities in Terms of Urban Good Governance in Shahrekords
}

\author{
Zohreh Hadiani ${ }^{1} \&$ Ezzatollah Ghasemi ${ }^{2}$ \\ ${ }^{1}$ Assistant Professor of Geography and Urban Planning, University of Sistan and Baluchestan, Iran \\ ${ }^{2}$ MSc in Geography and Urban Planning, University of Sistan and Baluchestan, Iran \\ Correspondence: Zohreh Hadiani, Assistant Professor of Geography and Urban Planning, University of Sistan \\ and Baluchestan, Iran. E-mail: z.hadyani@gep.usb.ac.ir/Eghasemi251@gmail.com
}

Received: April 27, 2016

Accepted: May 8, 2016

Online Published: May 27, 2016

doi:10.5539/mas.v10n9p46

URL: http://dx.doi.org/10.5539/mas.v10n9p46

\begin{abstract}
Nowadays, increasing cities population and difficulties due to the centralized programming approach that leading to the disorderliness in cities at one side and awareness and increasing citizens rights at the other side; necessitate the reexamining in urban management and city management. due to the radical changes in cities' developmental management, in addition to the mentioned approach, we need to deploy a decentralized approach in urban organization or apply a good urban governance with citizens cooperation simultaneously, so for removing current problems in urban development we should take into account the local organizations and governmental and non-governmental organization. The goal of this research is to consider Shahrekord performance in the framework of good urban governance. The research method is descriptive-analytical method, and data and information for this research gathered through field study and used measuring method, and subjects include sample of 330 shahrekod citizens. In this research we applied four standards for good urban governance i.e cooperation, efficiency, transparency and accountability, and for data processing and analyzing we used SPSS software. Findings show that efficiency has a mean equals to 2.95 , cooperation 2.67 , accountability with a satisfying mean equals to 2.59 , and transparency is 2.58 . so shahrekords' municipal performance in the framework of good performance is unsuitable, so research hypothesis which imply on suitable municipal performance at the framework of good urban management is unsatisfying and not being proven.
\end{abstract}

Keywords: good urban governance, cooperation, efficiency, transparency, accountability, Sharekord

\section{Introduction}

Human tendency for living in the cities clarified with wishing for welfare and security. in fact human have created cities for more welfare and security, and establishing shrines, palaces and food barns as well as production surplus and wealth density in cities, led to prioritize the security and this matter led to the creation of castles and bring a sense of security and welfare. even in contemporary cities, diversity at land and dwelling prices in different parts are related to the welfare and security level and we can model this.based on this process the rapid growth of civilization and urbanization of the globe will be understandable. Human in searching of more justice and freedom, welfare and more income and more facilities and suitable jobs rush into the cities. In the spite of such desires and expectations, we faced with overpopulation and shortage of resources and facilities in cities in all facets, causing that cities experience chronic problems such as rapid decline in living capabilities, ecological problems, living standards and experience other troubles such as injustice, pollution, poverty, unemployment, crime and insecurity. So nowadays, cities have been facing a dual and paradoxical landscape: at one view considered as a place for centralization of facilities, need providers, centers for development, advancement, business and welfare, and at the other side cities turned into places that all kind of problems have accumulated. Although, cities have the capacity to attract and flourish the human and economic investment, but this vantage point bring some negative points such as fine and crime, insecurity, pollution, time-wasting being noisy and overpopulation, conflicts, cold social relation and nervous difficulties and so on.Now more than the half of the world population live in the cities and world urban population from300 million at 1950 had reached to more than two and half billion_2,700,000,000_at 2000. Special report of United Nations at 2007 about population, due to the upmost attention, discussed the urbanization. at the other side by considering rapid development of urbanization in Iran and high level of tendency toward urbanization: Which in a 50_year period 
the number of cities from 199at 1335 had reached to 1012 at 1385 and urban population from $\% 32$ at 1335 had reached to \%68.5, we could reach to this conclusion that in the following years, urban management will be one of the big challenges in countries. So rapid urbanization in addition to the social, economical, cultural, and environmental difficulties, will be facing cities with managerial challenges (Rahnemaei, 2010, P. 24). Ongoing escalation of expansion scale as well as the complexity of urban issues and ineffectiveness of bureaucratic systems and top-down decision making process, lead to the creation of new systems, which great and small decision will made with the cooperation of urban beneficiary. Scientific and technological organizations which observed the intensifying challenges of urban management, and in the search of stability in urban management, so had been seeking modern solutions and wanted to establish stable development of humanistic city. Now they identified good governance as a most efficient, lowest costing, and most stable approach for management (Taqhavi, 2009, p. 45).

There's a centralized management in Iran cities, obviously such management is employing in Sharekord. Although this city had turned into a town at safawi era, but the organized management has been started in 1318 , the government of first Pahlawi. Based on the statistical numbers the population of this city from 15476 at 1335 had reached to 159755 at 1390, which experienced ten times bigger. By considering growth in population and its surpasses from urban and city developmental plans as well as continuous migration from other towns to this city, some difficulties have been arisen, which could mention to poverty, unemployment, slum, conflict between ethnics groups and their interests and instability, so at this research we had been trying to evaluate the performance of the Shahrekord by employing standards of good urban governance.

\section{Research Background}

Since governance, in a simple definition is a process of decision-making which decision deployed, and its history date back to the creation of human civilization. Although the application of urban governance has started at the late years of 1980s in Africa, but Brain Mack Lalyn was the first theorist who worked on this concept in 1973 (zibaei, 2008, P. 3). He believed that urban population have ongoing demands and the urban governance by considering continuous changes and process should be more accountable and responsible, its action might to be adjustable with changes and be more responsible toward society, and act as a part of learning system, and finally play the main role in predicting, exploring and welcoming of future. to realize such demands, the relationship with society and public organization is necessary. So by clarifying and statingabove introduction, Brain defined governance as a kind of process which includes both society and government and containing an interrelated institution (Burk poor, 2006. P. 491).

But about good urban governance, a lot of research have been conducting at the recent years by different universities and scientific centers, which among them we select the following cases:

Baris et al. study (2007): essential strategies for urban governance, had reached to this conclusion that for maximizing municipal success and achieve to the international and global level the upmost cooperation of citizens is necessary.

In a research: good urban governance in south-west of Asia, Pop qui sheng had reached to this conclusion, that decentralization and privatization lead to the improvement in urban governance as well as improvement in the efficiency of providing public services.

Alvbra et al. (2013) research: green economics and urban governance; evaluated good urban governance in urban economical process and provide mechanism for creating social systems and green economic bio-environment.

Emanuel (2014) research, good cooperative governance in Nigeria-backgrounds, statements and characteristics; had considered and clarified the backgrounds, and by considering organizational characteristics of institutions provide ways for exploiting and suitable usage of backgrounds and records, so finally could remove challenges.

In a survey by Taqhavi et al. (2009); introduction to the good urban governance; in an analytical approach they inspected and analyzed the related concepts with good governance, and by evaluating sample study from internal experiences from this approach, as well as emphasizing this matter that clear definition, institutionalized and strategic viewpoint to the good urban governance, could help up to experience stable management with more speed and more hope in towns and cities.

Rahnema et al. (2010) research about Mashhad city; analyzing good governance position with SWOT prototype; had reached to this conclusion that governance in Mashhad, by benchmarking four management mood i.e defensive, aggressive, conservative and competitive-currently is at the worst position i.e defensive mood, as well as in the case of interior factors (weakness and strength) is fragile and against exterior factors (threat and 
opportunity) didn't show suitable reaction.

Adinehwand et al. (2013), in an article considered municipal performance of Babolsar in the framework of good urban governance and found that cooperation with a mean equals to $(x=.024)$ is below average, efficiency and effectiveness are among important indices of good urban governance in Babolsar.

In a research; evaluation of municipals' performance in the framework good urban governance, conducted by Shamaei et al. (2012), they had reached to this conclusion that programming managers of Yassoj regardless of people opinion and only by considering organizational information, developed and programmed urban plans. Among compilations of good urban governance in Yassoj the level of cooperation and efficiency are under mean but accountability located at the higher level.

Ebrahimzadeh and Assadian (2013) in a survey in Kashmar, had analyzed and evaluated the amount of realization of good urban governance in Iran, and finding show that at the three basic indices of good urban governance which includes transparency and broadcasting, legitimacy, efficiency and effectiveness; after conducting T-Test the rate of sig was equals to $001 / 0$, which shows that the realization of such standards (indices) are at the low level.

It is clear from above researches that urban management in Iranian cities and towns have far distance with benchmarks of good urban governance. So municipal and urban managers for achieving a healthy and stable city as well as reach to the defined benchmarks should employ more suitable and adjustable standards and pay more attention to citizens' cooperation in the management of the cities. the goal of this research is to consider good urban governance position and identify and remove urban difficulties in Shahrekord city.

\section{Research Questions and Hypothesis}

Main question:

1. Does the municipal performance of Shahrekord have a satisfying performance in the framework of good urban governance?

Subordinate questions:

1. Is there cooperation between municipal and citizens on organizing city?

2. There is how much of accountability and responsibility of urban managers toward citizens?

3. There is how much of municipal efficiency in the framework good urban governance?

4. Does the municipal present the necessary information to the citizens in a clear and understandable way? How much of information present?

\section{Research Hypothesis}

That sounds the Shahrekord's municipal performance is suitable in the framework of good urban governance.

Research method and procedure

This research is a kindof descriptive-analytical, and necessary data and information gathered through documental studies as well as a massive part of the data gathered through field observation and measuring. The statistical society of the research are Shahrekord's citizens, which based on the published information by statistical center of iran, Shahrekord have population equals to 159775(20111). For calculating sample group we used cochran formula with standard error of 5 percent and with a certainty coefficient of 95 percent. The subject were 330 people of Shahrekord citizens, which for analyzing earned information through field study we used the SPSS software.

\section{Operational Definition and Theoretical Base}

Nrban management institution likewise other organization earns its meaning through interchange and interaction with society and citizens. Citizens intervention and cooperation in urban affairs is one of the original ways for national growth. Local enthusiastic cooperation and efficient experience about group organizing lead to encouraging citizens' desires for greater and national activities. And by recounting the experiences of useful local cooperation they wish to have greater role in national scale (Developmental experts believe, in the process of social and economical changes and transformation, citizens have the focus role and considered as a center for combination of sources, facilities and investments, so citizens cooperation is a driven power(Schumacher, 2010, p. 132). Management has a definition as programming organization, controlling and motivation creator; so when a city considered as an organization, for better organizing of the city we have to apply a special technique ie urban management (shiea, 2003, p. 39). urban management is a phenomenon that naturally have great vicinity 
with democracy and active cooperation of citizens in organizing. this principle needs a dynamic society.

In a such society managers considered as citizens agents, so that for achieving satisfaction they should be accountable. urban management structure account as one of the important facets of urban governance.

The (term) of good urban governance came into the development dialogue by the world bank(Sadashiva, 2008, p.7), then by international developmental institutions such as development bank of Asia (1995), international monetary funds (1996), United Nations development center (1997), deployed this word, and it was after these that turned to be a natural process of literature (Roberts et al., 2007, p. 970). United nations defines suitable governance as equal cooperation of all citizens in decision-making, that not only include governments, account civil society and markets, also. Which finally create legitimacy and group action. good urban governance from this viewpoint has a dual and paradoxical meaning: which at one side it relates to the experimental manifestation of government with exterior environment and at the other side it relates to the conceptual or theoretical pattern of social coordination and government role (bhuiyan, 2010, p. 162). governance has application in diverse contexts, which could imply to the integrated governance, international governance, national governance, private governance and local and urban governance, and at the same time it depends on the cooperation between government, private sector and civil society(Akbari, 2006, p. 150). This concept rely on this fundamental principle -instead that government take the whole responsibility lonely; it would be better to have coordination with all citizens, private sector and NGO's, and government should be considered as one of the responsible agents. By providing this interpretation government will take the role of facilitators and will ready the context for development of society in national, local and urban levels. By citizens cooperation as well as creation amore organized concept, civil society will be an arena for decision-making, policy-making and this revolution will change the management process of the country and from an imperious governance to a democratic and cooperative governance.( Rahnemaei \& Keshawarz, 2010, p. 42).

Governance is a pattern which realize with the interaction and cooperation of government, private sector and civil institutions with each other. In fact the interactive cooperation of these three elements lead to the progress of good governance and will facilitate that. in governance, government is one of the active elements and other cooperative and intervening elements depend on the roles and levels are different in the governance.

So, the nine basic principle of good urban governance are the following (based on United Nations manifesto).

Table1. Nine basic principle of good urban governance in the United Nations manifesto

\begin{tabular}{|c|c|c|}
\hline Row & Principle & efinition \\
\hline 1 & Cooperation & $\begin{array}{l}\text { Influential power on decision-making and sharing citizens in } \\
\text { decision-making }\end{array}$ \\
\hline 2 & Legiti & $\begin{array}{l}\text { In decision-making have efficient rules, observing justice and equal } \\
\text { rules in decision-making, don't allow to irresponsible people to } \\
\text { cooperate }\end{array}$ \\
\hline 3 & Tran & ncy is against concealment, and concealment will increase \\
\hline 4 & Accc & $\begin{array}{l}\text { This benchmark imply to being accountable; more clearly, the } \\
\text { managers be more responsible towards citizens. }\end{array}$ \\
\hline 5 & & etween diverse ben \\
\hline 6 & & are \\
\hline 7 & $\begin{array}{l}\text { Efficiency and } \\
\text { Effectiveness }\end{array}$ & $\begin{array}{l}\text { This benchmark pivot on suitable usage of current sources for } \\
\text { providing citizens needs and achieving satisfaction }\end{array}$ \\
\hline 8 & $\begin{array}{l}\text { Openness and } \\
\text { being responsible }\end{array}$ & $\begin{array}{l}\text { Urban managers should understand and accept citizens' need and } \\
\text { desires as well as show suitable reaction or response }\end{array}$ \\
\hline 9 & $\begin{array}{l}\text { Strategic } \\
\text { insight }\end{array}$ & $\begin{array}{l}\text { Presence of a universal and long term insight toward future and have } \\
\text { a optimist and strategic outlook about urban development }\end{array}$ \\
\hline
\end{tabular}

References; shamaei (2012), Ebrahimzadeh (2013)

Geographical position of the case study: Sharekord is the center of Chaharmahal and bakhteyari province, which located at the $100 \mathrm{~km}$ southwest distance of Esfahan, its altitude from see level equals 2200, and located at the longitude of between 50,50' and 50,52' eastern, and located at the latitude of between 32, 18' and 32, 20 'northern. In the case of political division it has two main areas, two urban districts and 35 inner 
parts.(municipal website of Sharekord)

\section{Findings of the Research}

For measuring function of municipality in the frame of good civic ruling in Kord city: Four parameters of partnership, efficiency, frankness and accountability have been used. In regard to the findings of the research each parameter has been discussed and analyzed.

\subsection{Partnership}

Partnership is a section in democracy category that form in the frame of citizenry terms and government, and power relationship in a society.(Sharifiyan thanni 2001:43). Based on Amartiyasen, partnership is people's ability in truth metamorphosis via social change, this parameter in a large-scale has been accepted as one of the fundamental dimensions of good civic ruling; so, by retroactive to concepts of social assets and uneconomical agencies of civic actors, we can say that partnership is a process of constant and continued ability for definition and analysis of issues, designing and arranging solutions, reflation and usage of resources in all levels of people's developmental necessities. Through those things actors can supervise and have control over the processes that effect their lives.(Pourmohamadi and et al 2011:43). for measuring partnership criterion five questions based on Likert scale which had five alternatives have been used. the results of statistical T-test showed this parameter with the average of 2.67 , is less than desirable average. It is evaluated undesirable.

Table 2. case evaluation of partnership parameter

\begin{tabular}{|c|c|c|c|c|c|c|c|}
\hline \multirow{3}{*}{ Component } & \multicolumn{7}{|c|}{ Test Value $=3$} \\
\hline & \multirow[t]{2}{*}{ mean } & \multirow[t]{2}{*}{$\begin{array}{l}\text { mean } \\
\text { difference }\end{array}$} & \multirow[t]{2}{*}{$\begin{array}{l}\text { Degrees of } \\
\text { freedom }\end{array}$} & \multirow[t]{2}{*}{$\mathrm{t}$} & \multirow[t]{2}{*}{ sig } & \multicolumn{2}{|c|}{$\begin{array}{l}\text { Confidence-inteval-of the } \\
\text { differince } 0 / 95\end{array}$} \\
\hline & & & & & & lower & Upper \\
\hline $\begin{array}{l}\text { peoples feedback on the } \\
\text { preparation of projects }\end{array}$ & 2.51 & -0.498 & 330 & 9.97 & 0.00 &.-.4001 & -5967 \\
\hline $\begin{array}{l}\text { People role on the } \\
\text { implementation of projects }\end{array}$ & 2.43 & -0.567 & 330 & -12.18 & 0.00 & -0.467 & -659 \\
\hline $\begin{array}{l}\text { Accountability in the } \\
\text { implementation ofprojects }\end{array}$ & 2.51 & -0.480 & 330 & -9.24 & 0.00 & -.378 & -582 \\
\hline $\begin{array}{l}\text { Authorities Assistance trend } \\
\text { for implementing projects }\end{array}$ & 3.45 & +0.456 & 330 & +8.53 & 0.00 &.+5613454 & 3510383 \\
\hline $\begin{array}{l}\text { roles of private institutes in } \\
\text { Urban Affairs. }\end{array}$ & 2.48 & -0.510 & 330 & -9.60 & 0.00 & -.0405 & -0.4059 \\
\hline $\begin{array}{ll}\text { General } & \text { index } \\
\text { (participation) } & \\
\end{array}$ & 2.67 & -0.324 & 330 & -14.87 & 0.00 & -0.227 & -0.279 \\
\hline
\end{tabular}

As the findings of the research show through questions relevant to partnership dimension, civilians of Kord township, people's function in plan administrating with the average of 2.43 the least amount of partnership and help intention to officials in plan administrating with the average of 3.45 have the highest amount of partnership. this indicating the high inclination of Kord township in partnership with civic managers.in this parameter acceptance of responsibility in administration of plans, polling from citizens in provision of plans and existence of private organizations in city affairs with the average of 51.50, -2.2, and 2.48 are in ranks of the second to fourth respectively.

\subsection{Efficiency}

Good civic ruling means processes and institutions present results which meet the needs of society and in addition exploit from the resources well. efficiency meaning, in good ruling domain also contains permanent use of natural resources and protection of environment. (Taqvaee \& Tajdar, 2009, p.53).paying attention to the meaning of efficiency, the researcher has used seven questions of five alternatives based on Likert scale. Concerning to the findings of the study, it was determined efficiency parameter with the average of 2.95 is relatively in a desirable level. 
Table 3. case evaluation of efficiency parameter

\begin{tabular}{|c|c|c|c|c|c|c|c|}
\hline \multirow{3}{*}{ Component } & \multicolumn{7}{|c|}{ Test Value $=3$} \\
\hline & \multirow[t]{2}{*}{ mean } & \multirow[t]{2}{*}{$\begin{array}{l}\text { mean } \\
\text { difference }\end{array}$} & \multirow[t]{2}{*}{$\begin{array}{l}\text { Degrees of } \\
\text { freedom }\end{array}$} & \multirow[t]{2}{*}{$\mathrm{t}$} & \multirow[t]{2}{*}{ sig } & \multicolumn{2}{|c|}{$\begin{array}{l}\text { Confidence- } \\
\text { inteval-of } \\
\text { differince } 0 / 95\end{array}$} \\
\hline & & & & & & uper & lower \\
\hline \multirow{3}{*}{$\begin{array}{l}\text { EnvironmentalProtection. } \\
\text { Satisfaction with municipal } \\
\text { services } \\
\text { sanctification from increasing } \\
\text { programs quality }\end{array}$} & 2.82 & -0.178 & 330 & -2.8 & .005 & -0530 & $.30-$ \\
\hline & 2.96 & -0.39 & 330 &.-680 & .497 & -.0743 & -.152 \\
\hline & 2.69 & -0.03 & 330 & -5.294 & 000 & -.189 & -.414 \\
\hline $\begin{array}{l}\text { Get as much as complications cost } \\
\text { it on urban airfares }\end{array}$ & 2.91 & -0.78 & 330 & -1.416 & .158. & $209-$ & -341 \\
\hline $\begin{array}{l}\text { Satisfaction from construction of } \\
\text { parks and green space }\end{array}$ & 3.42 & 0.42 & 330 & 6.979 & 000 & 546. & 305 \\
\hline $\begin{array}{l}\text { Satisfaction from street network } \\
\text { and access }\end{array}$ & 2.90 & -0.93 & 330 & -1.521 & .129 & -.027 & -214 \\
\hline \multirow{2}{*}{$\begin{array}{l}\text { municipal success on civil affairs } \\
\text { overall index (performance) }\end{array}$} & 2.96 & 0.039 & 327 & -621 & .535 & -0.085 & \multirow{2}{*}{$\begin{array}{l}-165 \\
0.078\end{array}$} \\
\hline & 2.95 & 0.045 & 327 & -2.103 & 0.036 & -.0029 & \\
\hline
\end{tabular}

Findings of the research show that among different parts of efficiency parameter, park construction and greenbelt with the average of 3.42the highest desirability and environment preservation with the average of 2.82 contains the least desirability.

\subsection{Frankness}

Frankness opposes hiding in decision making. Hiding increases eruption possibility of corruption in decision making. Nevertheless, frankness prevents corruption expansion. This criterion stabilizes on free circulation, easy availability of information, openness of measurement and continued awareness of citizens from present procedures. (Tavakulineya and colleagues, 2012, p.143); so taking this parameter into account six questions were evaluated and results show this parameter with the average of 2.58 is situated in undesirable level.

Table 4. case evaluation of frankness parameter of Kord township municipality in the frame of good civic

\begin{tabular}{|c|c|c|c|c|c|c|c|}
\hline \multirow{3}{*}{ Component } & \multicolumn{7}{|c|}{ Test Value $=3$} \\
\hline & \multirow[t]{2}{*}{ mean } & \multirow[t]{2}{*}{$\begin{array}{l}\text { mean } \\
\text { difference }\end{array}$} & \multirow[t]{2}{*}{$\begin{array}{l}\text { Degrees of } \\
\text { freedom }\end{array}$} & \multirow[t]{2}{*}{$\mathrm{t}$} & \multirow[t]{2}{*}{ sig } & \multicolumn{2}{|c|}{$\begin{array}{l}\text { Confidence-inteval-of the } \\
\text { differince } 0 / 95\end{array}$} \\
\hline & & & & & & upper & lower \\
\hline $\begin{array}{l}\text { notice about construction } \\
\text { work }\end{array}$ & 2.2 & -71 & 330 & -1034 & 0.00 & -579 & -852 \\
\hline $\begin{array}{l}\text { notice from Cost and } \\
\text { schedule details }\end{array}$ & 2.35 & -64 & 330 & -9.098 & 0.00 & -506 & -78 \\
\hline $\begin{array}{ll}\text { citizen awareness } & \text { of } \\
\text { programs and decisions of } & \\
\text { city council } & \end{array}$ & 2.5 & -48 & 330 & 7.081 & 0.00 & -.346 & -6138 \\
\hline $\begin{array}{l}\text { Clash of the corruption in } \\
\text { municipalities }\end{array}$ & 2.83 & -16 & 330 & -2.91 & 0.00 & -539 & -278 \\
\hline $\begin{array}{l}\text { The integrity of urban } \\
\text { management }\end{array}$ & 2.59 & -41 & 330 & -5.04 & 0.00 & -249 & -562 \\
\hline $\begin{array}{l}\text { the implementation of } \\
\text { directors promises }\end{array}$ & 2.95 & -48 & 330 & -1.034 & 193 & .430 & -212 \\
\hline $\begin{array}{l}\text { The overall index } \\
\text { transparency }\end{array}$ & $2 / 58$ & -41 & 330 & -13.92 & 0.00 & -3579 & -475 \\
\hline
\end{tabular}


The finding of the study show in frankness parameter the practicability balance of managers 'promising with the average of 2.91 the highest level of desirability and act of apprising with the average of 2.28 has the least level of desirability.

\subsection{Responsibility and Accountability}

Each kind of amending program for improvement of quality, the government needs special attention to two basic values, namely, it points to considering the common people, accountability of the government to the people, and responsibility of the government to the circumstances of real function to the programs which are administrated by civic managers constitutions, in other words, these constitutions should be responsible in relation to the affect of their politics major section of the society. This criterion stabilizes on responsibility and in a more open phrase, it stabilizes on the accountability of the authorities and decision-makers against citizens; therefore, there is a necessity in existing procedures for accountability of authorities. Accountability is a principal subject in good civic ruling. if the level of accountability is low, the outlines of responsibility will become vague.(Torabey and colleagues, 2014, p.6). In the present research for measuring accountability parameter of Kord township municipality eight questions were evaluated. Deducing results from questionnaires show that accountability parameter with 2.59 is situated in a lower level of the average.

Table 5. Case evaluation of accountability in Kord township municipality in the frame of good civic ruling

\begin{tabular}{|c|c|c|c|c|c|c|c|}
\hline \multirow[t]{2}{*}{ Component } & \multirow[t]{2}{*}{ mean } & \multirow[t]{2}{*}{$\begin{array}{l}\text { mean } \\
\text { difference }\end{array}$} & \multirow[t]{2}{*}{$\begin{array}{l}\text { Degrees of } \\
\text { freedom }\end{array}$} & \multirow[t]{2}{*}{$\mathrm{t}$} & \multirow[t]{2}{*}{$\operatorname{sig}$} & \multicolumn{2}{|c|}{$\begin{array}{l}\text { Confidence-inteval-of the } \\
\text { differince } 0 / 95\end{array}$} \\
\hline & & & & & & upper & lower \\
\hline $\begin{array}{l}\text { Responsibility for dealing } \\
\text { with citizens affairs }\end{array}$ & $2 / 57$ & -0.422 & 330 & $-8 / 69$ & 0.000 & -327 & -518 \\
\hline $\begin{array}{l}\text { Question and answer } \\
\text { sessions to the needs of } \\
\text { people }\end{array}$ & $2 / 44$ & -0.552 & 330 & $-10 / 69$ & 0.000 & -451 & -654 \\
\hline $\begin{array}{l}\text { sanctification from city } \\
\text { managers treatments }\end{array}$ & $2 / 65$ & .0347 & 330 & $-6 / 36$ & 0.000 & -240 & -0.454 \\
\hline connection comfort with city & $2 / 37$ & -625 & 330 & $-11 / 90$ & 0.000 & -522 & -0.728 \\
\hline $\begin{array}{l}\text { managersProgram } \\
\text { description } \\
\text { achieving favorable results }\end{array}$ & $2 / 77$ & -0.510 & 330 & $-4 / 245$ & 0.000 & -118 & -0.322 \\
\hline $\begin{array}{l}\text { When referring to } \\
\text { municipalities }\end{array}$ & $2 / 69$ & -0.220 & 330 & $-6 / 48$ & 0.000 & -0.212 & -397 \\
\hline $\begin{array}{l}\text { Responding to the needs of } \\
\text { citizens }\end{array}$ & $2 / 66$ & -0.238 & 330 & $-5 / 59$ & 0.000 & -219 & -457 \\
\hline overall index accountability & $2 / 59$ & -0401 & 330 & $-19 / 84$ & 0.000 & -0.441 & -0.362 \\
\hline
\end{tabular}

Regarding to the finding of the research, it was specified that in accountability parameter the level of program explanation with the average of 2.77 has the highest level of desirability and convenient relationship with managers has the average of 2.27 the least level of desirability.

\section{Conclusion}

Civic ruling is a process that from one direction forms based on reciprocal action among organizations and formal constitutions of controlling city and from another direction it forms among non-governmental organizations and civil society formations ;in other words, civic ruling is a kind of process and relationship between civic governorship and citizens which contains both civic governorship and civil society, and emphasizes on vindication and reinforcement of public open-spaces.in fact good civic ruling in civil management is desirable when it has citizens 'satisfaction. Desirable civil try in regarding to criteria of good civic ruling, reply to the needs and wishes of the citizens idealy. in this research has been used four criteria of good civic ruling contains: partnership, efficiency, frankness, responsibility and accountability for measuring this subject. the results of the research show in relation to the main questions and hypothesis quest the desirability function of shaharKord township municipality in the frame of good civic ruling.

The municipality function of the mentioned city in good civic ruling is relatively undesired.in relation to the minor questions of the research, partnership parameter with the average of 2.67 , is relatively undesired level, 
efficiency parameter with the average of 2.91 , is in a desirable level, frankness parameter with the average of 2.58 , undesired level and accountability parameter with the satisfactory average of 2.59 is relatively undesired. These averages indicate undesirability of good civic ruling in municipality of Kord city. Therefore, based on the present research and its findings for making desirable of the municipality function in the frame of good civic ruling in shahrKord city and other same citiesthe researcher presents below offers:

1. Maximum partnership of citizens in civil affairs and partnership in provision and administrating the plans.

2. Informing of people in time and frankness in relation to the civil affairs to the citizens.

3. Suitable and in time accountability to the people when they refer to the municipality.

\section{References}

Adegbite, E. (2014). Good corporate governance in Nigeria: Antecedents, propositions and peculiarities. International Business Review.

Adinehvand, A. A., Hajizadeh, M., \& Ghadami, M. (2003). Reviews the performance of municipalities in the context of good governance and a model study (Babolsar). Journal of Urban Management, 31, Spring and Summer.

Akbry, G. (2006). social capital and urban governance. Geographical Research Quarterly, No. 83. Isfahan.

Bandz, M. (2011). urban social theory, (the city, and society), translations doctor R. Rural Tehran University Publications, First Edition.

Barakpoor, N. (2006). urban governance and urban management system in Iran, conference planning and urban management.

Barakpoor, N., \& Asadi, I. (2009). Management and urban governance, publications Research Department of Art University, Tehran.

Batterbury, S. P. J., \& Fernando, J. L. (2006). Rescaling governance and the impacts of political and environmental decentralization: anintroduction. World Development, 34(11), 1851-1863.

Bhuiyan, S. H. (2010), A crisis in governance: urban solid waste management inBangladesh. Habitat international, 34, 125- 133.

Burriss, S. T., Hancock, Lin, V., \& Herzog, A. (2007). Emerging Strategies for Healthy Urban Governance. Journal of Urban HealthBulletin of the New York Academy of Medicine, The New York Academy of Medicine.

Chaharmahal and Bakhtiari Province, Planning Department, Office of Statistics and Information, Department of the Gis.

Ebrahimzadeh, I., \& Assadian, M. (2013). analyze and evaluate the extent of realization of urban good governance in Iran Case study: Kashmar city. Journal of Geography and Urban Planning Regional, Issue 6, Spring.

Frzynpak, S. (2004). The Mvkhtnyhay city, good governance mean? Press municipalities.

General census of population and housing. (2011). the Statistical Center of Iran.

Gore T., \& Wells, P. (2009). Governance and evaluation: The case of EU regional policy -horizontal priorities. Evaluation and program, 2009(32), 158-167.

Oliveira, J., Christopher, D., Osman, B., Ping, J., Magali, D., Aki, S., Raquel, M., \& Puspita, D. (2013). Green economy and governance in cities: Assessing good governancein key urban economic processes. Journal of Cleaner Production, 2013(58), 138-152.

Pour-Mohammadi, M., Hossein, Z., Dalir, K., \& Old, I. (2011). A city on the basis of good governance, social capital. Geographical Studies Arid Areas, 1, 52-35.

Qly, P. R. (2008). Good governance and a model state. Islamic Azad University, Open Office of Science.

Rahnama, M. R., Mafi, E., \& Assadi, R. (2010). Analyzing the role of good governance in Mashhad city with a swot. Journal of Geography and Regional Development, 15. Autumn and Winter.

Rhnmayy, M. T., \& Keshavarz, M. (2010). Evaluation of good governance and the role of government in the management of city affairs in Iran. Journal of Geography and Regional Planning of the first year, 1, Spring and Summer. 
Roberts, S. M., Wright, S., \& O’Neil, P. H. (2007). Good governance in the Pacific? Ambivalence and possibility, Geoforum, 2007(38), 967- 984.

Sadashiva, M. (2008). Effects 28-of civil society on urban planning and governance in Meysore. India, Doctoral thesis, Technical university of Dortmund.

Schumacher, E. F. (2010). Small is Beautiful, translated by Ali Ramin, Fifth Edition, published by Soroush, Tehran.

Shamaei, A., Adinehvand, A. A., \& Hajizadeh, M. (2012). Evaluating the performance of municipalities on urban good governance (Case Study: Yasouj), fourth-year studies on urban management / No. 11 / autumn.

Sharifian, T. M. (2001). Citizen participation, urban governance and urban management, urban management Quarterly, No. 8, Winter.

Sheng, Y. K. (2010). Good Governance in Southeast Asia, Environment and Urbanization ASIA, 1131-147.

Shia, E. (2003). The need for change in Iran's urban management. Journal of Geography and Development, the spring and summer, 77-62.

Torabi, Z., Mazidi, A. R., \& Firuzi, M. A. (2014). Evaluate the performance of the municipality of the city of Gorgan in the context of good governance. International Conference on Green Economy.

Tusi, M. A. (2001). Participation in the management and ownership, the fourteenth edition of Tehran Public Administration Training Center.

Zibayi, N. (2009). Urban govern ance, the underlying stability of the city. Retrieved from http://citymanager.blogfa.com

\section{Copyrights}

Copyright for this article is retained by the author(s), with first publication rights granted to the journal.

This is an open-access article distributed under the terms and conditions of the Creative Commons Attribution license (http://creativecommons.org/licenses/by/3.0/). 